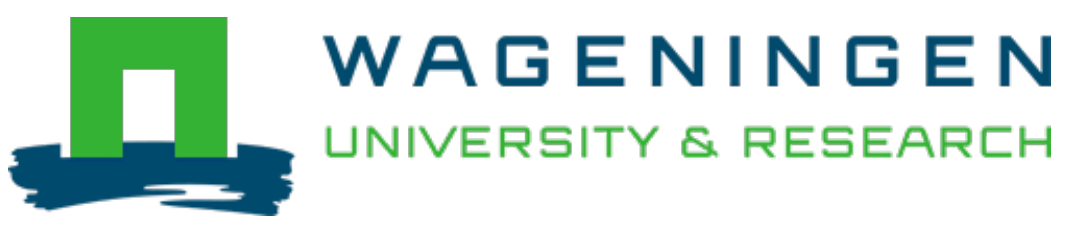

\author{
Nitrogen emissions along global livestock supply chains \\ Nature Food \\ Uwizeye, Aimable; Boer, I.J.M.; Opio, Carolyn; Schulte, R.P.O.; Falcucci, Alessandra et al \\ https://doi.org/10.1038/s43016-020-0113-y
}

This article is made publicly available in the institutional repository of Wageningen University and Research, under the terms of article $25 \mathrm{fa}$ of the Dutch Copyright Act, also known as the Amendment Taverne. This has been done with explicit consent by the author.

Article $25 \mathrm{fa}$ states that the author of a short scientific work funded either wholly or partially by Dutch public funds is entitled to make that work publicly available for no consideration following a reasonable period of time after the work was first published, provided that clear reference is made to the source of the first publication of the work.

This publication is distributed under The Association of Universities in the Netherlands (VSNU) 'Article $25 \mathrm{fa}$ implementation' project. In this project research outputs of researchers employed by Dutch Universities that comply with the legal requirements of Article $25 \mathrm{fa}$ of the Dutch Copyright Act are distributed online and free of cost or other barriers in institutional repositories. Research outputs are distributed six months after their first online publication in the original published version and with proper attribution to the source of the original publication.

You are permitted to download and use the publication for personal purposes. All rights remain with the author(s) and / or copyright owner(s) of this work. Any use of the publication or parts of it other than authorised under article $25 \mathrm{fa}$ of the Dutch Copyright act is prohibited. Wageningen University \& Research and the author(s) of this publication shall not be held responsible or liable for any damages resulting from your (re)use of this publication.

For questions regarding the public availability of this article please contact openscience.library@wur.nl 


\title{
Nitrogen emissions along global livestock supply chains
}

\author{
Aimable Uwizeye ${ }^{1,2}$, Imke J. M. de Boer2 , Carolyn I. Opio', Rogier P. O. Schulte ${ }^{3}$, Alessandra Falcucci', \\ Giuseppe Tempio', Félix Teillard', Flavia Casu', Monica Rulli', James N. Galloway4, \\ Adrian Leip ${ }^{5}$, Jan Willem Erisman ${ }^{6}$, Timothy P. Robinson', Henning Steinfeld ${ }^{1}$ \\ and Pierre J. Gerber ${ }^{2,7}$
}

\begin{abstract}
Global livestock supply chains have significantly altered nitrogen ( $N$ ) flows over past years, thereby threatening environmental and human health. Here, we provide a disaggregated assessment of the livestock sector's impacts on global $\mathbf{N}$ flows and emissions, including international trade. The results show that the sector currently emits $65 \mathrm{Tg} \mathrm{N} \mathrm{yr}^{-1}$, equivalent to one-third of current human-induced $\mathbf{N}$ emissions and sufficient to meet the planetary boundary for $\mathbf{N}$. Of that amount, $66 \%$ is allocated to Asia and $68 \%$ is associated with feed production. Most emissions originate from locally produced animal-sourced food, although $\mathbf{N}$ emissions embedded in international trade are significant for some importing countries. Given the magnitude of its impacts and its central role in both domestic and international $\mathbf{N}$ challenges, the livestock sector urgently requires a global initiative to tackle $\mathbf{N}$ pollution while supporting food security.
\end{abstract}

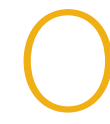

ver the past few decades, livestock systems across the world have been transformed from local, small-scale, mixed crop-livestock systems to global, demand-driven supply chains, in which animals are often spatially disconnected from the production of the feed they consume ${ }^{1,2}$. These changes, largely driven by economic opportunities, have altered the way in which the livestock sector impacts global nitrogen $(\mathrm{N})$ biogeochemical flows, which have transgressed the planetary boundary for $\mathrm{N}$ (refs. ${ }^{3,4}$ ) and caused a range of environmental effects ${ }^{5}$. Currently, just 50 countries, accounting for $75 \%$ of the global population ${ }^{6}$, consume around $95 \%$ of synthetic $\mathrm{N}$ fertilizer ${ }^{7}$.

The livestock sector contributes to global $\mathrm{N}$ flows through the application of synthetic $\mathrm{N}$ fertilizer and manure to both cropland and grassland, the management and accumulation of manure, and the transport of $\mathrm{N}$-rich products such as feed, food and manure ${ }^{8}$. These developments have changed the pattern of atmospheric $\mathrm{N}$ emissions such as nitrous oxide $\left(\mathrm{N}_{2} \mathrm{O}\right)$, a potent greenhouse gas, as well as ammonia $\left(\mathrm{NH}_{3}\right)$ and nitrogen oxides $\left(\mathrm{NO}_{x}\right)$, which contribute to air pollution, pose risks to human health and cause eutrophication and acidification ${ }^{9,10}$. Emissions of nitrates $\left(\mathrm{NO}_{3}^{-}\right)$and organic $\mathrm{N}$, two common sources of water pollution and biodiversity loss ${ }^{5,11-13}$, have also increased.

The United Nations 2030 Agenda for Sustainable Development ${ }^{14}$ has highlighted the urgency with which these environmental threats must be understood and mitigated. Existing literature has increasingly considered livestock as components of broader food systems ${ }^{8,15-17}$ or the global economy ${ }^{18}$; however, the level of aggregation of most analyses does not allow measures to be drawn specifically for the livestock sector. A recent study has provided a more detailed analysis of global acidification and eutrophication induced by the production of animal-sourced food ${ }^{19}$, but this relied mostly on observations from commercial farms in industrialized countries. A comprehensive analysis of the contribution of the livestock sector to $\mathrm{N}$ emissions for the European Union found that livestock supply chains represented $82 \%$ of total agricultural $\mathrm{NH}_{3}$ emissions and $73 \%$ of all agricultural $\mathrm{N}$ emissions to water bodies ${ }^{20}$. So far, no work has performed a global, yet disaggregated assessment (that is, spatially explicit and distinguishing between different species, commodities and systems) of $\mathrm{N}$ use in livestock supply chains and their contribution to global $\mathrm{N}$ emissions.

We fill this knowledge gap by elucidating the magnitude and diversity of $\mathrm{N}$ flows and the resulting emissions in global livestock supply chains from 'cradle-to-primary-processing gate of animal products', while accounting for international trade. Our study covers 275 countries and territories grouped in 10 regions and uses an updated version of the Global Livestock Environmental Assessment Model (GLEAM) ${ }^{21}$ for 2010. We use the most detailed geo-referenced information available, highlighting the diversity of livestock supply chains and international trade. Furthermore, we quantify $\mathrm{N}$-use indicators of life-cycle nitrogen use efficiency and life-cycle net nitrogen balance (see Methods), identifying hotspots of $\mathrm{N}$ emissions and ultimately suggesting targeted interventions to reduce emissions (Supplementary Discussion).

\section{Results}

$\mathbf{N}$ emissions from the livestock sector. Our analysis shows that livestock supply chains contributed $\sim 65 \mathrm{TgN}^{-1}$ to global human-induced $\mathrm{N}$ emissions in 2010, in the form of $\mathrm{NO}_{3}-$ $\left(29 \mathrm{TgNyr}^{-1}\right), \mathrm{NH}_{3}\left(26 \mathrm{TgNyr}^{-1}\right), \mathrm{NO}_{x}\left(8 \mathrm{TgNyr}^{-1}\right)$ and $\mathrm{N}_{2} \mathrm{O}$ $\left(2 \mathrm{Tg} \mathrm{Nyr}^{-1}\right.$ ) (Fig. 1). These emissions represented $\sim 39 \%$ of anthropogenic $\mathrm{NO}_{3}{ }^{-}$released to surface and groundwater, $60 \%$ of total $\mathrm{NH}_{3}$ emissions, $23 \%$ of $\mathrm{NO}_{x}$ emissions and $32 \%$ of $\mathrm{N}_{2} \mathrm{O}$ emissions

${ }^{1}$ Food and Agriculture Organization of the United Nations, Animal Production and Health Division, Viale delle Terme di Caracalla, Rome, Italy. ${ }^{2}$ Animal Production Systems group, Wageningen University \& Research, Wageningen, the Netherlands. ${ }^{3}$ Farming Systems Ecology group, Wageningen University \& Research, Wageningen, the Netherlands. ${ }^{4}$ Department of Environmental Sciences, University of Virginia, Charlottesville, VA, USA. ${ }^{5}$ European Commission, Joint Research Centre, Ispra, Italy. ${ }^{6}$ Louis Bolk Institute, Driebergen, the Netherlands. ${ }^{7}$ The World Bank Group, Agriculture and Food Global Practice, NW Washington, DC, USA. $\bigotimes_{e}$-mail: aimable.uwizeye@outlook.com 


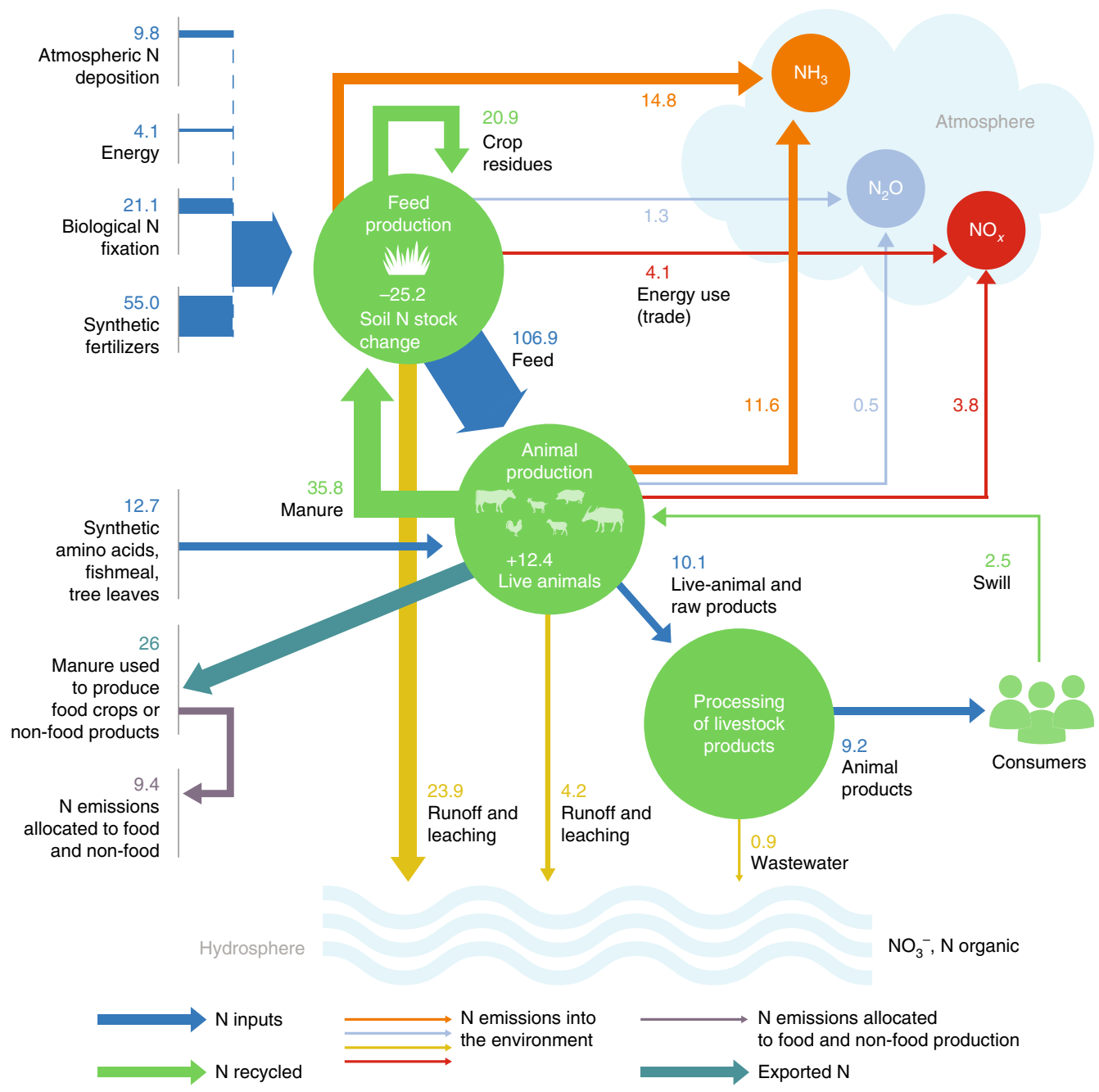

Fig. 1 | Global $\mathbf{N}$ flows and sources of $\mathbf{N}$ compound emissions allocated to the livestock sector. $\mathbf{N}$ emissions associated with manure used to produce food crops and non-food products are aggregated. Losses of $\mathrm{N}_{2}$ to the atmosphere from manure management systems are estimated at $8.3 \mathrm{Tg} \mathrm{Nyr}{ }^{-1}$ and are not shown here. All numbers are expressed in $\mathrm{Tg} \mathrm{Nyr}^{-1}$.

globally ${ }^{18}$. The bulk of $\mathrm{N}$ emissions takes place during feed production and manure management systems (Fig. 1). Feed production releases around $44 \mathrm{TgNyr}^{-1}$, in particular through manure deposited on grasslands, manure spreading and synthetic fertilizer application to croplands. Manure management in the animal production stage is the second main source of $\mathrm{N}$ emissions, with $\sim 20 \mathrm{Tg} \mathrm{Nyr}^{-1}$ lost through volatilization, $\mathrm{N}$ leaching and manure used to produce energy. $\mathrm{N}$ emissions from the processing of animal-sourced food are minor in comparison $\left(\sim 1 \mathrm{TgNyr}^{-1}\right)$.

Livestock emissions represent $\sim 35 \%$ of estimated $\mathrm{N}$ emissions from the agricultural sector ${ }^{15,16}$ and $~ 29-34 \%$ of $\mathrm{N}$ emissions from the entire global economy ${ }^{11,18}$ (Supplementary Discussion). Acknowledging the methodological differences and uncertainties of these global estimates, we estimate that the sector represents about one-third of global human-induced $\mathrm{N}$ emissions. We also estimate that total synthetic fertilizer and biological $\mathrm{N}$ fixation used to produce livestock feed $\left(76 \mathrm{TgN} \mathrm{yr}^{-1}\right)$ (Fig. 1) has already reach the planetary boundary for nitrogen (that is, $\left.62-82 \mathrm{TgNyr}^{-1}\right)^{3}$.

N emissions per supply chain. Globally, ruminant supply chains of milk, meat and co-products such as hides and skins release $\sim 46 \mathrm{Tg} \mathrm{Nyr}^{-1}$ (or $71 \%$ of the total $\mathrm{N}$ emissions from livestock), with the production of eggs and meat from chicken and pork contributing the remaining 29\% (Fig. 2a and Supplementary Methods).
More specifically, mixed cattle and buffalo supply chains alone are responsible for $44 \%$ of the total $\mathrm{N}$ emissions, with most of it taking place in South Asia (Fig. 2). Supply chains of grazing cattle (dairy and beef) and pig (backyard, intermediate and industrial) each account for $\sim 16 \%$ of total $\mathrm{N}$ emissions, with the latter concentrated in East and Southeast Asia (Fig. 2b). The projected expansion of total animal production (74\%) in low- and middle-income regions by $2028^{22}$ is likely to further increase $\mathrm{N}$ emissions from these systems.

Regional hotspots of $\mathbf{N}$ emissions. Most $\mathrm{N}$ emissions take place in the regions of South Asia $\left(23 \mathrm{TgN} \mathrm{yr}^{-1}\right)$, East and Southeast Asia $\left(18 \mathrm{TgNyr}^{-1}\right)$ and Latin America and the Caribbean $\left(7 \mathrm{TgNyr}^{-1}\right)$, given the high numbers of livestock held in mixed and grazing ruminant systems and backyard monogastric systems (Fig. 2a,b). In South Asia, large buffalo and cattle populations with low productivity are responsible for $87 \%$ of regional livestock $\mathrm{N}$ emissions. In Latin America and the Caribbean and North America, beef and dairy cattle production systems account for $72 \%$ of $\mathrm{N}$ emissions. Cattle production contributes considerably to $\mathrm{N}$ emissions in Sub-Saharan Africa, North Africa and the Near East, while pigs and cattle are the main contributors in Western and Eastern Europe (Fig. 2).

We observe considerable spatial variability in disaggregated $\mathrm{N}$ emissions along livestock supply chains per unit of land 
a
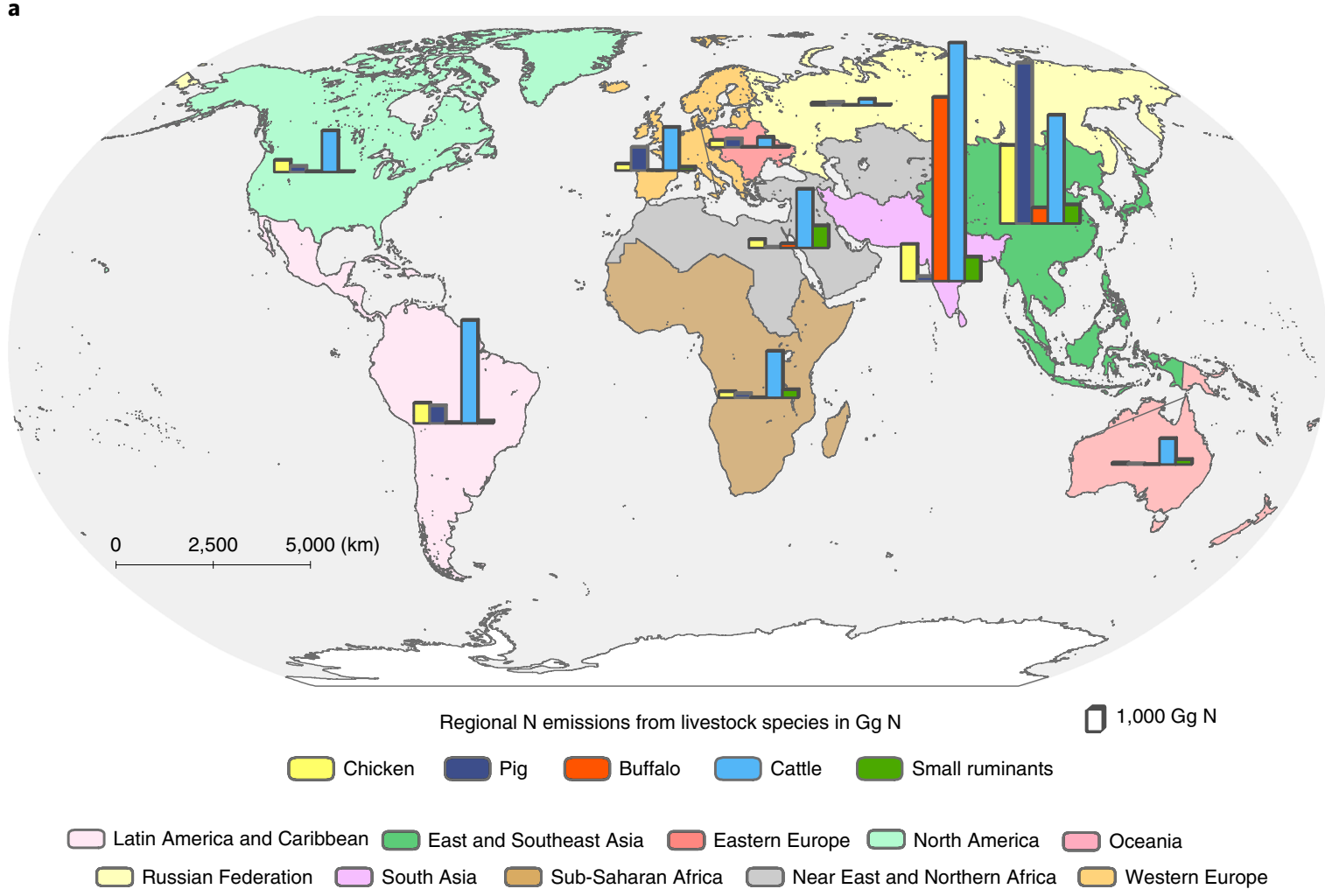

b

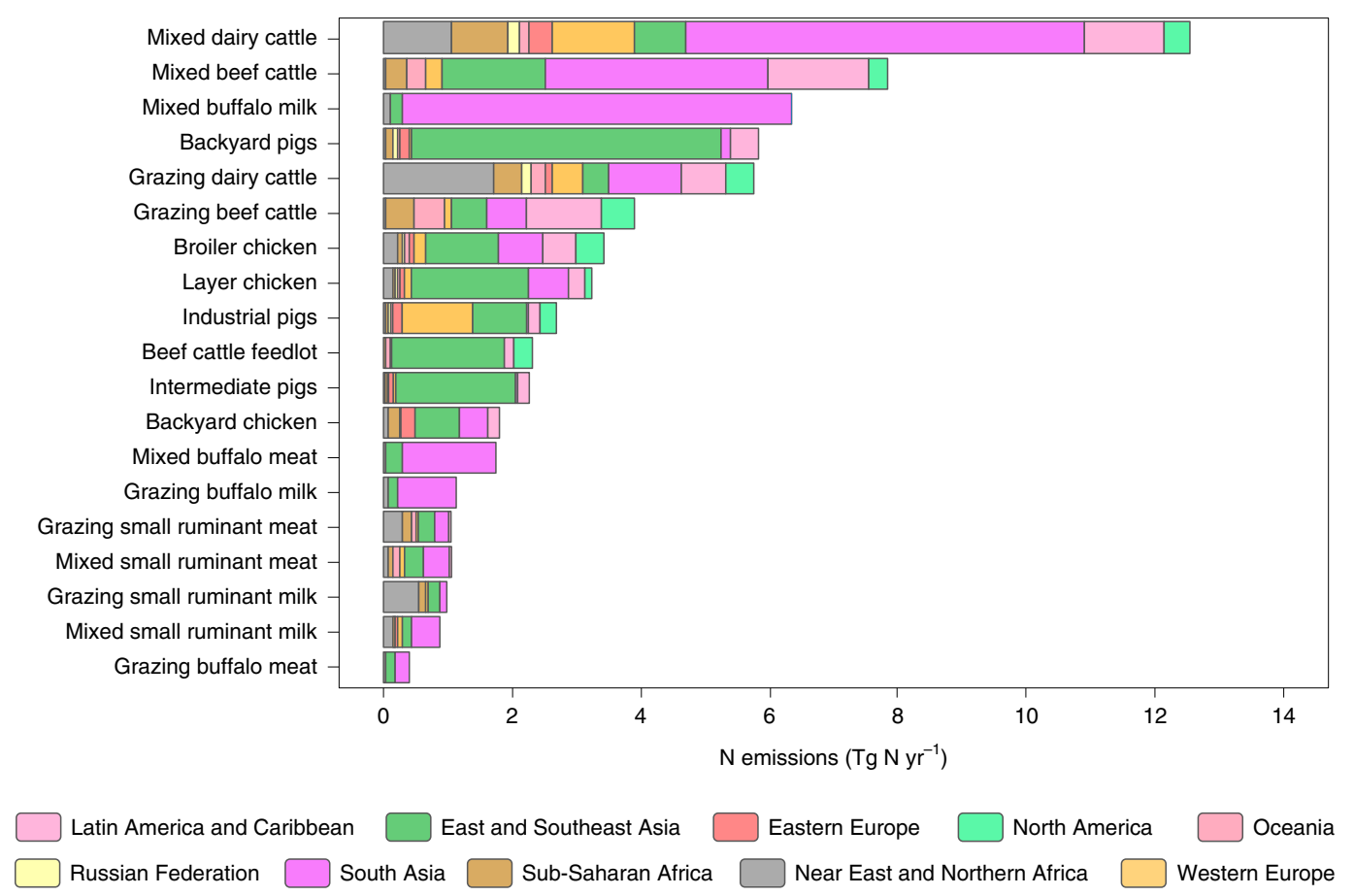

Fig. 2 | Disaggregated global $\mathrm{N}$ emissions from livestock supply chains. a, Distribution of $\mathrm{N}$ emissions by livestock species for 10 regions (in $\mathrm{Gg} \mathrm{N}^{\mathrm{r}} \mathrm{r}^{-1}$ ). b, Regional contribution of different livestock systems to total $\mathrm{N}$ emissions (in $\mathrm{Tg} \mathrm{Nyr}^{-1}$ ).

(Figs. 3a,b and 4). $\mathrm{N}$ emissions are allocated to the grid cell where animals are located, even if, in reality, they take place at another location (see Methods). Most $\mathrm{N}_{2} \mathrm{O}$ emissions from pig, chicken and cattle systems take place in Western Europe, East and Southeast Asia, Oceania and Latin America (Fig. 3a). $\mathrm{NH}_{3}$ emissions are concentrated in East and Southeast Asia, Oceania (East Australia and New Zealand), Western Europe, Latin America (Colombia),
North America (east coast of the United States) and the Nile Delta (Fig. 3b). High $\mathrm{NO}_{3}{ }^{-}$emissions are modelled for the Indo-Gangetic plain, East and Southeast Asia, the Nile Delta and Latin America (Fig. 4). In the Indo-Gangetic plain, emissions are related to a high density of cattle and buffalo and are associated with poor manure management, high synthetic fertilizer applications and the use of manure as fuel ${ }^{23}$. In most East Asian countries, high $\mathrm{NH}_{3}, \mathrm{~N}_{2} \mathrm{O}$ and 
a

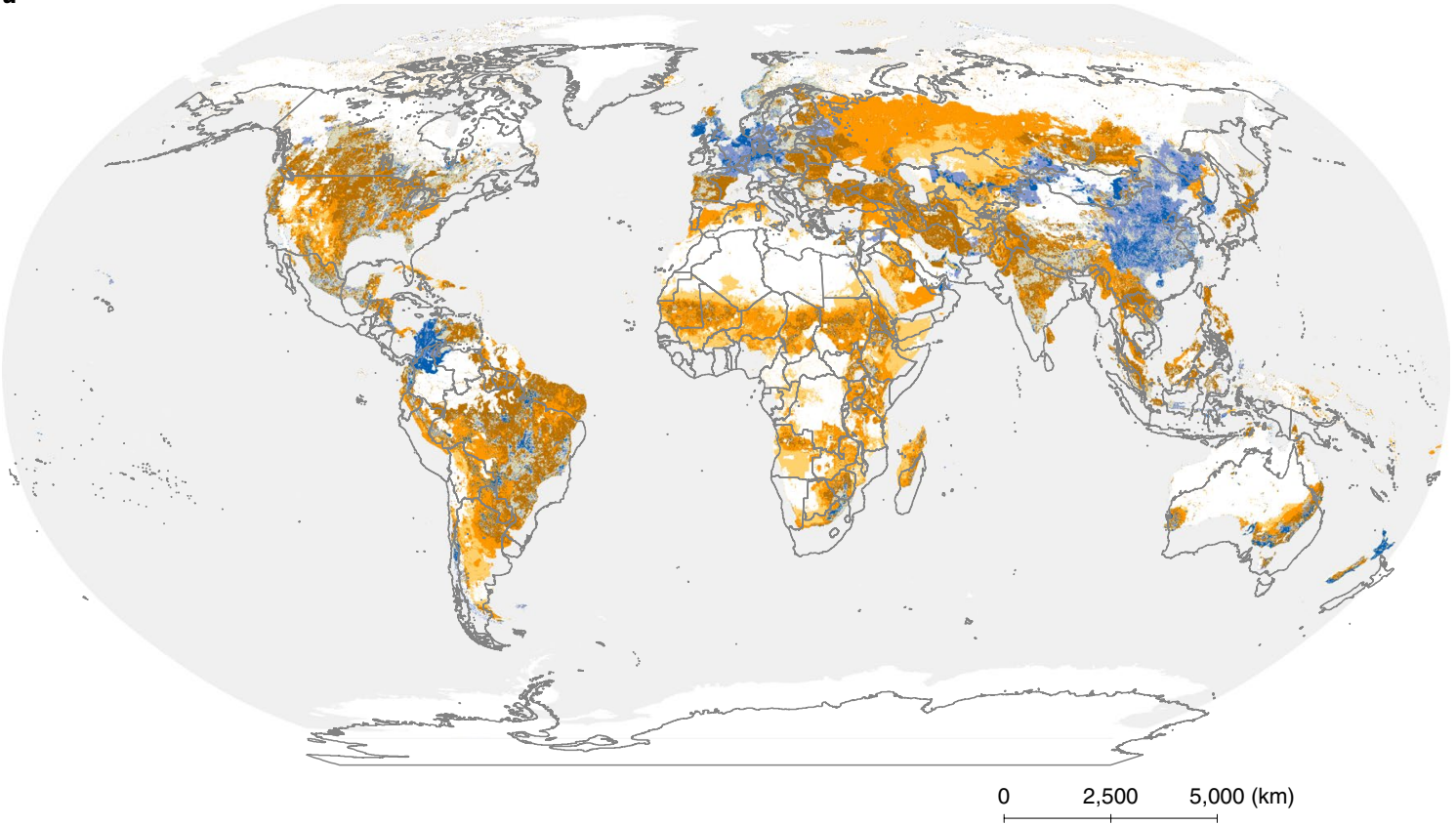

$\mathrm{N}_{2} \mathrm{O}$ emissions from livestock supply chains $\left(\mathrm{kg} \mathrm{N}-\mathrm{N}_{2} \mathrm{O} \mathrm{ha}^{-1}\right)$

$<.5$
$0.5-1 \quad \square_{1-1.5}^{1.5-2} \square 2-2.5 \square>2.5$

Animal density $<1$ livestock unit per sq. km

b

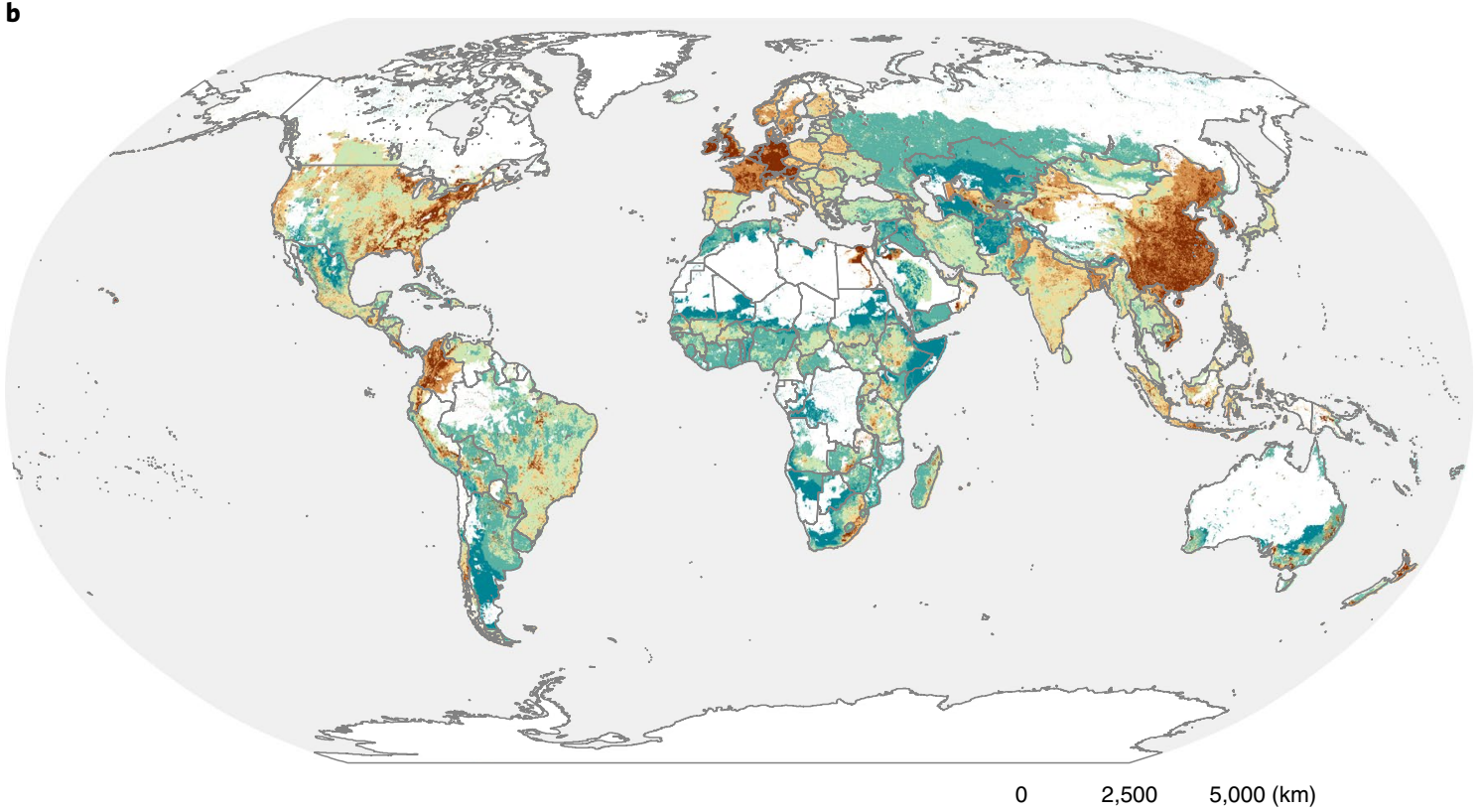

$\mathrm{NH}_{3}$ emissions from livestock supply chains $\left(\mathrm{kg} \mathrm{N}^{-\mathrm{NH}_{3}} \mathrm{ha}^{-1}\right)$
$<7$
$7-14$
14-21
$21-28$
28-35
$>35$
Animal density $<1$ livestock unit per sq. $\mathrm{km}$

Fig. 3 | Global distribution of $\mathrm{N}_{2} \mathrm{O}$ and $\mathbf{N H}_{3}$ emissions from livestock supply chains. a, Spatial distribution of $\mathrm{N}_{2} \mathrm{O}$ emissions. b, Spatial distribution of $\mathrm{NH}_{3}$ emissions. Emissions are aggregated for all livestock species and consist of $\mathrm{N}_{2} \mathrm{O}$ and $\mathrm{NH}_{3}$ emissions taking place in feed production and animal production (manure management systems) per hectare of land used to produce feed.

$\mathrm{NO}_{3}{ }^{-}$emissions are explained by the geographical concentration of animals in large-scale farms (industrial pig, chicken and mixed dairy cattle) and backyard pig farms, and are associated with unregulated manure disposal and high synthetic fertilizer application rates. These systems produce more manure than can be recycled in the surrounding agricultural area-on which synthetic fertilizer is concurrently applied-resulting in high emissions per unit of area. For Latin America, high emissions per hectare of land used to 


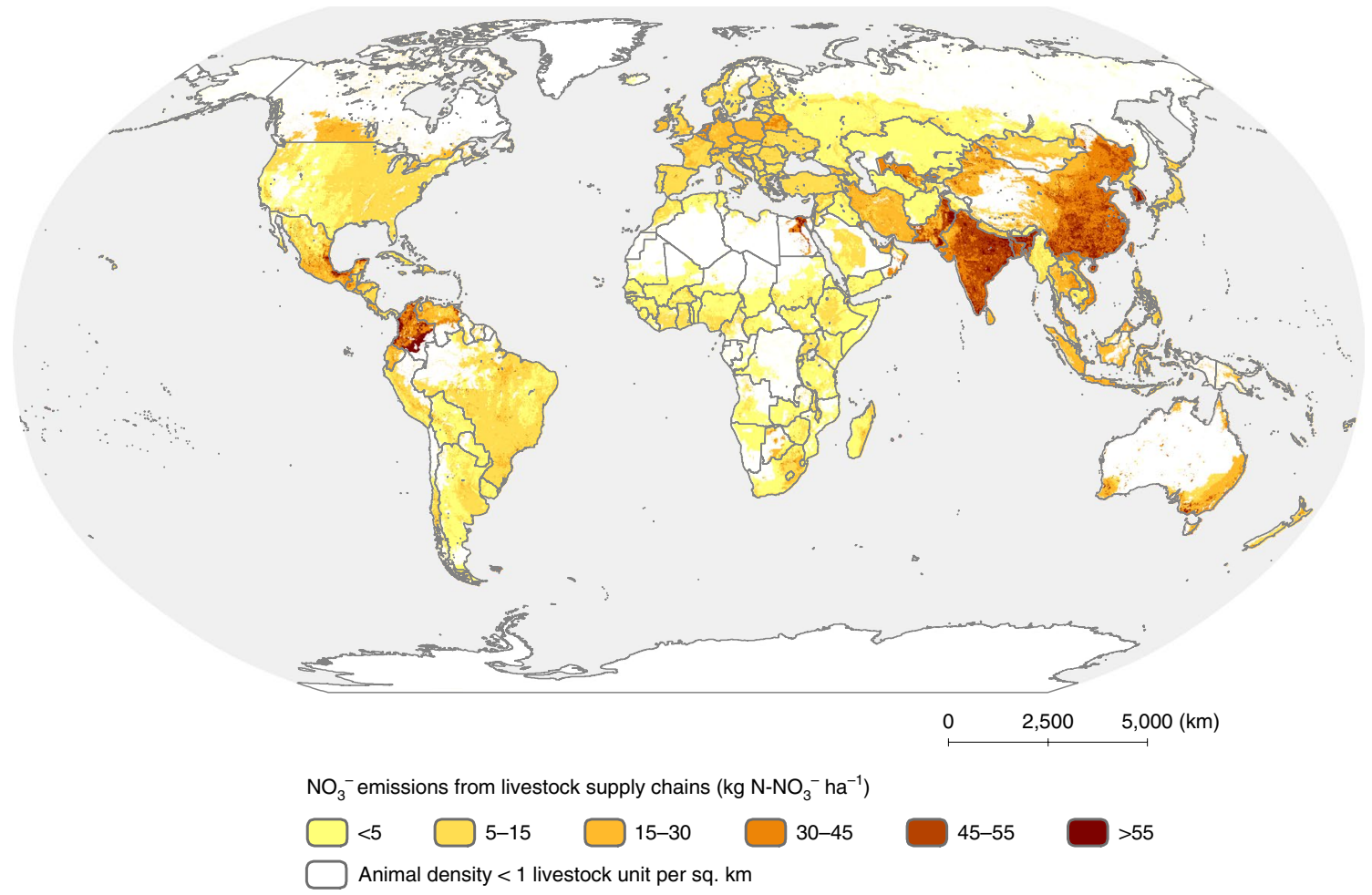

Fig. 4 | Spatial distribution of $\mathrm{NO}_{3}{ }^{-}$emissions to surface and groundwater from livestock supply chains. $\mathrm{N}$ emissions are aggregated for all livestock species and consist of $\mathrm{NO}_{3}^{-}$emissions taking place in feed production, animal production (manure management) and processing of animal-sourced food per hectare of land used to produce feed.

produce feed are related to backyard pig and chicken supply chains that rely mostly on swill and scavenging for feed, considered in our analysis to be of low land requirements (zero land use allocation). Here, $\mathrm{N}$ emissions follow the uneven distribution of livestock densities, and their concentrations in certain hotspots result in regional $\mathrm{N}$ pollution levels that exceed regional $\mathrm{N}$ boundaries ${ }^{13,24}$ (Extended Data Fig. 1).

$\mathbf{N}$ indicators across regions and systems. We analysed life-cycle $\mathrm{N}$-use efficiency (life-cycle-NUE $\mathrm{N}_{\mathrm{N}}$ ), that is, the efficiency of recovering $\mathrm{N}$ mobilized at each stage into the animal-sourced food, across livestock supply chains (Fig. 5a and Supplementary Methods). Our results show variability across countries and livestock systems, indicating considerable differences with respect to livestock management practices, feed resources, animal performance and improvement potential around the world. Except for beef cattle feedlots, this variability is most pronounced in ruminant systems, reflecting the relative diversity observed in these systems in terms of species, breeds, practices and size ${ }^{25}$.

The highest life-cycle-NUE $\mathrm{N}_{\mathrm{N}}$ values were computed for the three poultry systems, ranging from $32-67 \%$ for broiler, to $6-60 \%$ for backyard chickens and 3-60\% for layers (Fig. 5a). The results for the seven ruminant-meat systems are far more diverse, ranging between 1 and $72 \%$. Among those, large ruminants show lower life-cycle-NUE $\mathrm{N}_{\mathrm{N}}$ values than small ruminants. These trends are explained by differences in management practices, feed sources and animal genetics, with a larger diversity among ruminants ${ }^{26,27}$.

Life-cycle net nitrogen balance (life-cycle-NNB ${ }_{\mathrm{N}}$ ) is calculated by aggregating the $\mathrm{N}$ losses, regardless of the geographical location where they take place across the supply chain, and dividing the sum of the land area required to produce feed and fodder (Fig. 5b and Supplementary Methods). The lowest median life-cycle- $\mathrm{NNB}_{\mathrm{N}}$ values are computed for supply chains that either generate relatively low $\mathrm{N}$ emissions (for example, broiler chickens or industrial pigs) or that use large agricultural areas to produce feed (for example, small ruminants), which effectively dilutes the emissions per unit of land. The high median values computed for backyard pigs and chicken supply chains result from the zero land use allocation to the production of swill.

$\mathbf{N}$ emissions from domestic consumption. Embedded $\mathrm{N}$ emissions from the production of internationally traded livestock commodities (either in the form of traded feed or animal-sourced food) amount to $\sim 5.5 \mathrm{TgNyr}^{-1}$ ( $8 \%$ of total emissions) (Fig. 6). These emissions are driven by the volume of internationally traded commodities and $\mathrm{N}$ emissions associated per unit of product in the exporting country.

For feed commodities, $\mathrm{N}$ emissions generated in exporting countries are estimated at $1.5 \mathrm{Tg} \mathrm{Nyr}^{-1}$ and relate mostly to the fertilization of feed (Fig. 6a and Supplementary Figs. 1 and 2). Of this amount, $59 \%$ is associated with the trade of cereals (wheat, barley and maize, with a total traded volume of $6.4 \mathrm{Mt}$ ), $39 \%$ with soybean and soybean cake trade (with a traded volume of $1.2 \mathrm{Mt}$ ) and $2 \%$ with the trade in palm products and cassava. Most of these emissions take place in five exporting countries where feed production has expanded because of the availability of land, low-cost synthetic fertilizer, mechanization and energy-namely the United States (21\%), Australia (13\%), India (12\%), Brazil (12\%) and Argentina (7\%). Of the importing countries, China (18\% of embedded $\mathrm{N}$ emissions), Japan ( $6 \%$ of embedded $\mathrm{N}$ emissions), Iran, Indonesia and the Netherlands (4\% of embedded $\mathrm{N}$ emissions each) are reallocating $\mathrm{N}$ emissions from where they import feed: demand for feed in China, for example, generates $261 \mathrm{Gg}$ of $\mathrm{N}$ emissions in several countries, including the United States (42\%, mostly from soybean production), Australia (24\%, mostly from barley and wheat production) and Brazil (17\%, mostly from soybean production). Similarly, 


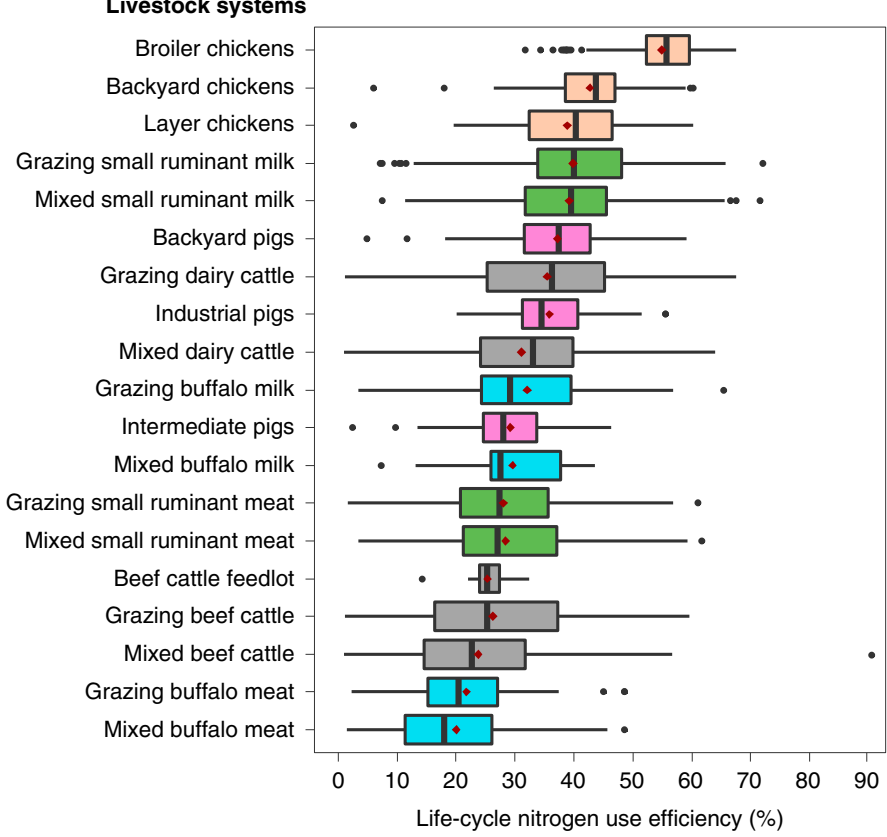

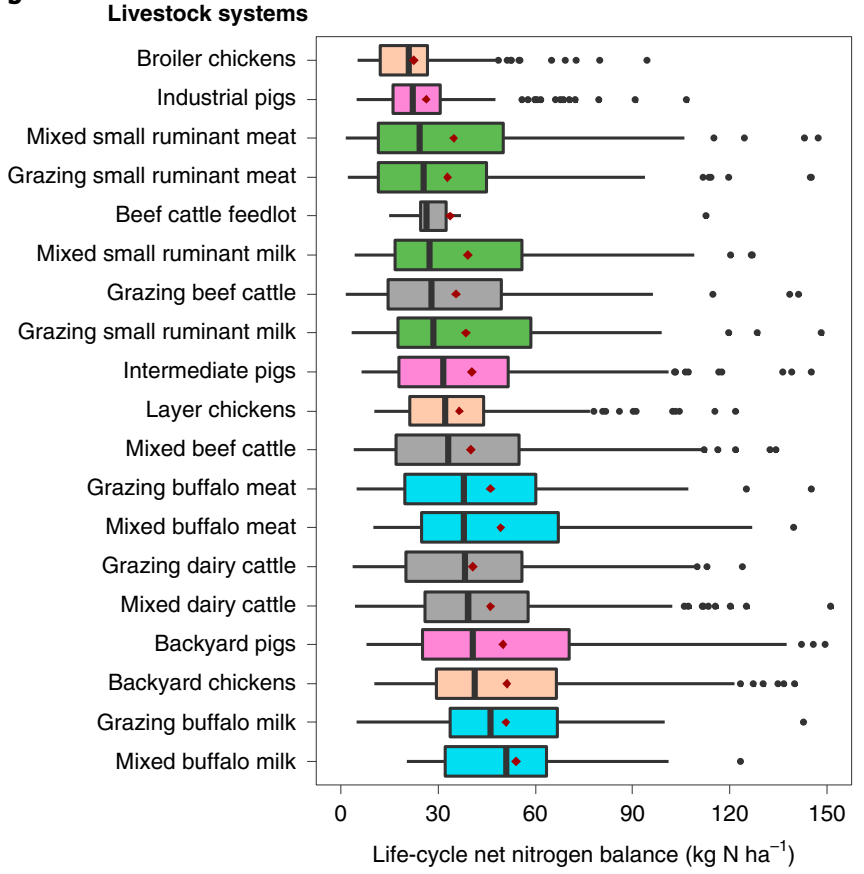

Fig. 5 | Distribution of $\mathbf{N}$ indicators by species, commodity and systems. a, Life-cycle nitrogen use efficiency. The systems are ranked in decreasing order of the median values. b, Life-cycle net nitrogen balance. The systems are ranked in increasing order of the median values. In both graphs, boxes represent the 25th to 75th percentiles, the centre lines indicate median, the diamonds show means and the dots represent outliers. The colour indicates the livestock species. To better visualize the results, values above $150 \mathrm{~kg} \mathrm{~N} \mathrm{ha}^{-1}$ were excluded from $\mathbf{b}$.

demand for feed in Japan generates $83 \mathrm{Gg}$ of $\mathrm{N}$ emissions in the United States (30\%, from soybean, maize and wheat), Australia ( $27 \%$, from barley and wheat), India ( $14 \%$, from soybean) and China (10\%, from soybean and maize).

Emissions embedded in the trade of animal commodities include emissions from all stages of production (that is, feed and animal production) and geographical locations along the supply chain. They are estimated at $\sim 4 \mathrm{TgNyr}^{-1}$ (Fig. $6 \mathrm{~b}$ and Supplementary Figs. 3-5) and stem from the production of beef (41\%), milk (31\%), pork (15\%), chicken meat $(8 \%)$, sheep meat $(3 \%)$ and eggs $(1 \%)$. Most of these emissions take place in major exporting countries: Australia (21\%), Germany (8\%), Brazil (8\%), the Netherlands (7\%), United States (7\%), Canada (5\%) and New Zealand (4\%). In New Zealand, Australia and the United States, embedded $\mathrm{N}$ emissions are associated with the export of beef and milk products, whereas in Brazil they are associated with the export of beef and chicken meat. For Germany, the Netherlands and France, dairy product exports are the driver of embedded $\mathrm{N}$ emissions. Regarding importers, the consumption of beef in Japan is linked to $262 \mathrm{Gg} \mathrm{N}$ emissions in Australia, while Japan's imports of meat (beef, chicken and pork) from the United States are associated with $\sim 29 \mathrm{Gg} \mathrm{N}$ of emissions. These embedded $\mathrm{N}$ emissions are in line with previous estimates ${ }^{18}$. The consumption of beef in the Republic of Korea and the Russian Federation relates to $\sim 235 \mathrm{Gg} \mathrm{N}$ emissions in Australia, Brazil and the United States, while demand for livestock products in Germany, the Russian Federation, United States and the United Kingdom is linked to $\sim 951 \mathrm{Gg} \mathrm{N}$ emissions in Australia, New Zealand, United States and the Netherlands.

\section{Discussion}

This study provides a disaggregated assessment of global $\mathrm{N}$ use and emissions, using a consistent level of granularity and precision for all supply chains. Except for $\mathrm{NO}_{x}$ emissions, the estimated emissions of single $\mathrm{N}$ compounds found in this study are lower than those previously reported ${ }^{28}$, despite the subsequent increase in animal herds between 2000 and 2010 (Supplementary Table 5). Some previous studies have used default $\mathrm{N}$ excretion factors ${ }^{29}$, default emission factors and an empirical model to estimate $\mathrm{N}$ emissions from the field and manure ${ }^{28}$. Contrastingly, our study relies on the latest methods ${ }^{30,31}$ for the manure model and $\mathrm{N}$ dynamics in the soils and allocates only a share of $\mathrm{N}$ emissions from manure management systems to animal-sourced food. Our higher estimates for $\mathrm{NO}_{x}$ emissions are due to the inclusion of on-farm energy use and international transport of feed and livestock commodities, which had not been considered ${ }^{28}$ (Supplementary Discussion).

Regarding embedded $\mathrm{N}$ emissions in major exporting countries (such as Australia, Brazil and the United States), they take place in geographically concentrated farms ${ }^{32}$. This situation is fuelled by the increasing global demand for feed and livestock commodities in Asia. For example, export volumes of beef from the United States have grown at an average annual rate of $7 \%$ during the past three decades $^{6}$. For the importers, the displaced $\mathrm{N}$ emissions through international trade are not included in national inventories, leading to a lack of domestic policies to increase $\mathrm{N}$ use efficiency along the entire value chain.

Given the complexity of the model we used, the assumptions therein and the need for global detailed data to populate the model, significant uncertainties arise (Supplementary Discussion). Yet, our estimate of the substantial contribution of the livestock sector to global $\mathrm{N}$ emissions is robust (Supplementary Discussion) and our analysis allows for the drivers of $\mathrm{N}$ emissions worldwide to be identified. These drivers are described in the Supplementary Discussion, together with a brief discussion of mitigation options.

Livestock supply chains are a major source of $\mathrm{N}$ emissions, contributing roughly one-third of global anthropogenic emissions, with significant impacts on pollution, climate change and biodiversity losses ${ }^{33}$. Our study has shown how traded commodities carry embedded emission across borders, which is in agreement with previous studies ${ }^{18,34}$. These findings highlight the need to renew policy attention to nutrient pollution from livestock supply chains and to 
a

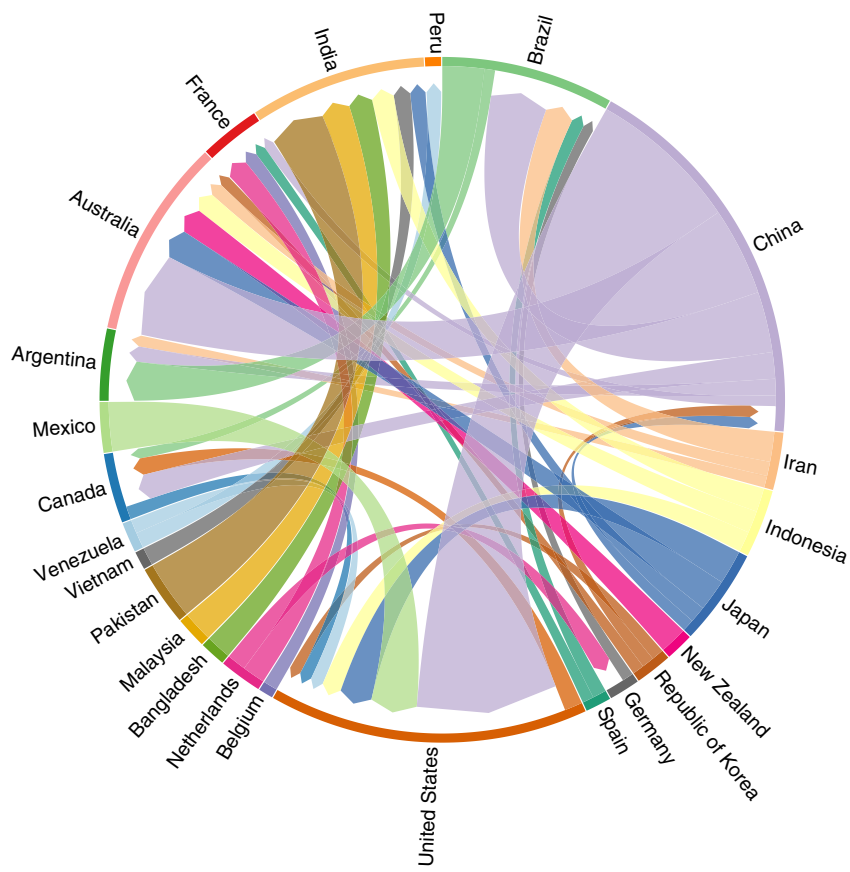

b

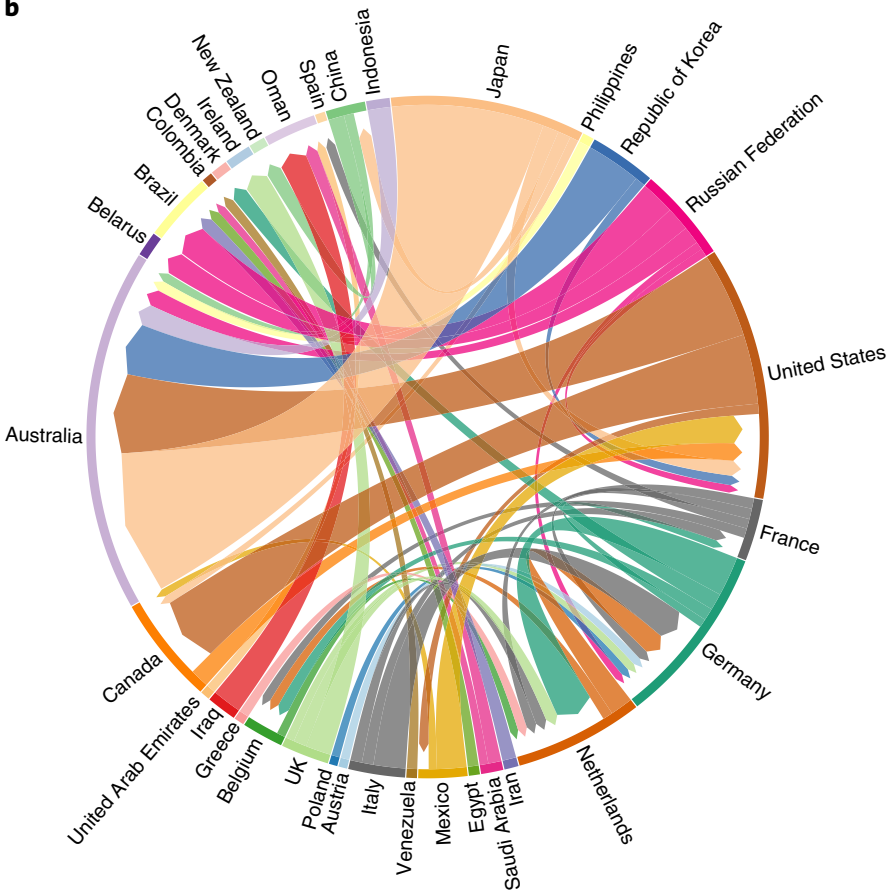

Fig. 6 | Embedded $\mathbf{N}$ emissions in international trade of feed and livestock commodities. a, Feed commodities (1.5 Tg $\mathrm{N} \mathrm{yr}^{-1}$ ). $\mathbf{b}$, Livestock commodities including feed used to produce them ( $4 \mathrm{Tg} \mathrm{N} \mathrm{yr}^{-1}$ ). The ribbon colours distinguish the countries of import and export and the arrowhead of each ribbon points to $\mathrm{N}$ emissions caused in each exporting country by a given importing country. The size of the arrow indicates the relative magnitude of embedded $\mathrm{N}$ emissions in each graph. The direction of the arrow indicates the attribution of $\mathrm{N}$ emissions in imported commodities. For clarity, we represent only the major flows (representing $50 \%$ of embedded $\mathrm{N}$ emissions).

develop initiatives consistent with the increasingly transnational nature of the issue.

This analysis has identified a few regions and supply chains where most $\mathrm{N}$ emissions are taking place. Targeting national $\mathrm{N}$ management policies and regional collaboration towards these hotspots is expected to improve the cost-effectiveness of actions. For example, fertilizer policies in South Asia, East and Southeast Asia and North America can be improved to consider locally available sources of $\mathrm{N}$, including crop residues and manure ${ }^{35}$. We showed that emissions take place at all stages of the supply chain, but are mostly related to feed production for ruminant systems-except in mixed buffalo meat and cattle systems - and manure management for monogastric systems (Supplementary Table 4). Strategies concomitantly targeting sources of $\mathrm{N}$ emissions from feed and livestock production are required, acknowledging that nutrient emissions are largely driven by the spatial disconnect between animal and crop production (feed or food). The two are often produced separately, particularly in the large-scale mixed cattle, feedlot beef, pig and poultry operations purchasing most of the feed materials (Supplementary Table 4). Incentivizing farmers to collect, transport and recycle manure to available croplands could help reduce $\mathrm{N}$ emissions, but this intervention is often limited by high transportation costs ${ }^{36,37}$. Designing a livestock production system that is spatially less concentrated and where feed and livestock are regionally integrated could improve $\mathrm{N}$ efficiency ${ }^{38,39}$ in North America, Western Europe and East and Southeast Asia.

Technical solutions and good practices, however, may not be sufficient to reduce impacts to acceptable levels ${ }^{19}$. In parts of the world, a reduction in the production and consumption of livestock products is probably necessary to keep global $\mathrm{N}$ emissions within planetary boundaries ${ }^{17,19,40}$. Such reduction should not come at the expense of food security ${ }^{41,42}$, particularly in contexts where livestock plays a major role in addressing malnutrition and building food systems' resilience to climate change $e^{43,44}$. Rather, it should be considered in a targeted way, appreciating the large diversity of livestock systems and their contribution to food security and poverty eradication, together with the many products and services they provide $^{43,45}$.

The need for an intergovernmental coordination mechanism on nitrogen policies has been recognized in the resolution of the United Nations Environment Assembly (UNEA-4) on sustainable nitrogen management ${ }^{46}$. In light of the magnitude and complexity of our results, we recommend the creation of a global initiative to tackle $\mathrm{N}$ pollution, with representation from the public and private sectors, civil society, academia, as well as stakeholders from the livestock and agriculture supply chain. Such an initiative should provide a platform for science-based dialogue on policies to mitigate $\mathrm{N}$ pollution from the livestock sector and support the development of integrated solutions for natural resource governance, markets information, standards and regulations, along with awareness-raising and advisory services ${ }^{47}$. This integrated approach would also help to address the many trade-offs between $\mathrm{N}$ management and other sustainability goals.

\section{Methods}

The GLEAM model. The Global Livestock Environmental Assessment Model (GLEAM) is a spatially explicit biophysical model developed at the Food and Agriculture Organization of the United Nations (FAO) to assess the contribution of global livestock supply chains to environmental issues ${ }^{21}$. It is based on a life-cycle assessment and covers the main stages of livestock supply chains, including feed production, animal production, processing of animal products and transportation. GLEAM has been used to estimate the contribution of livestock systems to global human-induced emissions of greenhouse gase ${ }^{26}$ and has been further developed, for the purposes of this study, to estimate $\mathrm{N}$ flows and associated emissions. A description of GLEAM 2.0, the specific version used in this Article, is available at http://www.fao.org/gleam/resources/en/.

GLEAM accounts for $\mathrm{N}$ flows and emissions at a resolution of $5 \mathrm{arcmin}$, for combinations of species, commodities, production systems and agro-ecological 
zones. We model $\mathrm{N}$ flows and emissions in three stages of the livestock supply chains: feed production (including farm mechanization, fertilization, international transport and processing), animal production (including manure management systems) and processing of animal products and transport. We apply the indicator framework developed by Uwizeye et al. ${ }^{48}$ to estimate life-cycle-NUE $\mathrm{N}_{\mathrm{N}}$ and life-cycle-NNB $\mathrm{N}_{\mathrm{N}}$ based on supply-and-use matrices (Supplementary Methods). These indicators are calculated using four matrices: (1) $\mathrm{N}$ embodied in the final products at each stage $(P) ;(2) \mathrm{N}$ transferred from one stage to another or recycled, which contains loops (for example, crop residues) and feedbacks (for example, manure) (I); (3) $\mathrm{N}$ resulting from $\mathrm{N}$ stock change at each stage $(S)$; (4) $\mathrm{N}$ fixed biologically or industrially from nature or sourced from other agricultural activities $(M)$ and $\mathrm{N}$ losses at each stage $(L)$ (Supplementary Table 9 ). These matrices are used to estimate $\mathrm{N}$ use indicators for each supply chain. For the life-cycle-NUE $\mathrm{N}_{\mathrm{N}}$

$$
M^{\star}=M(P-I+\hat{S})^{-1}
$$

where $M^{*}$ is the amount of $\mathrm{N}$ required to recover $1 \mathrm{kgN}$ in the animal products and $\hat{S}$ is the diagonal matrix of $\mathrm{N}$ stock changes induced by each unit process

$$
\text { Life-cycle-NUE }{ }_{\mathrm{N}}=1 / M_{\mathrm{p}}^{*}
$$

where $M_{\mathrm{p}}^{*}$ is the third element of the matrix $M^{*}$ related to the processing stage of animal products.

For the life-cycle-NNB

$$
\text { Life-cycle-NNB } \mathrm{N}_{\mathrm{N}}=\frac{\sum L F}{A}
$$

where $L$ refers to the total $\mathrm{N}$ emissions at each stage, $F$ refers to a biophysical allocation factor between co-products at each stage and $A$ refers to the total land required to produce feed.

Model development. Specific new developments of GLEAM were carried out to perform this analysis ${ }^{21}$. An overview is provided in Supplementary Fig. 6.

$N$ modelling in soils. We have upgraded the feed module in GLEAM to account for all sources of $\mathrm{N}$ input to the soil, including biological $\mathrm{N}$ fixation, synthetic fertilizer, manure, crop residues and atmospheric $\mathrm{N}$ deposition and soil $\mathrm{N}$ stock change. We incorporated a stepwise approach to reflect the $\mathrm{N}$ mass balance for each feed item and to account for $\mathrm{N}$ emissions from each source of $\mathrm{N}$ inputs ${ }^{21}$. For feed items produced within a country, $\mathrm{N}$ emissions were estimated as the sum of $\mathrm{N}$ losses via volatilization, runoff and leaching. For imported feed items, $\mathrm{N}$ input data and yields were estimated as the national average in exporting countries weighted by the trade volumes reported in the FAO trade matrix (Supplementary Methods). We used the Intergovernmental Panel on Climate Change (IPCC) method (Tier 2) ${ }^{49}$ to estimate $\mathrm{NH}_{3}$ volatilization and $\mathrm{N}_{2} \mathrm{O}$ emissions from soils, then combined the information on global land cover, slope and precipitation to calculate $\mathrm{NO}_{3}{ }^{-}$loads via runoff ${ }^{50}$ (Supplementary Methods). The fraction of $\mathrm{N}$ emissions via leaching was estimated using a mass balance approach. We also estimated $\mathrm{NO}_{x}$ emissions from field operations, transport and manufacturing of synthetic fertilizer and pesticides, and harvesting and crop processing using a proxy of the $\mathrm{CO}_{2}$ to $\mathrm{NO}_{x}$ ratio $^{21,5 \mathrm{I}}$

$N$ modelling in international transport. Trade matrices were initially obtained from FAOSTAT for the individual feed (for example, soybean cake and maize bran) and livestock items (for example, milk whole fresh cow and meat cattle boneless; Supplementary Methods). To homogenize year-to-year variations in trade flows, a three-year average (2009-2011) was calculated. We then computed trade matrices for aggregated feed items (for example, soy, maize and wheat) and livestock items (for example, eggs hen in shell, meat cattle and meat chicken) by summing individual items and applying FAOSTAT conversion factors to distinguish crop primary and secondary products ${ }^{52,53}$ (Supplementary Methods).

For each exporting country, if the exported quantity was higher than that produced, the difference was considered as re-export. Thus, the proportion of re-exports to total exports was calculated and assumed similar for each aggregated item and all its related individual items. For every single item, trade flows between re-exporters and final importers were reallocated to flows between primary exporters and final importers. This reallocation was done proportionally: re-exported commodities were reassigned to primary exporters, according to their relative contribution to the imports of re-exporters. These re-exported commodities were then allocated to final importers according to their relative contribution to the exports of re-exporters. For each item, the result was a corrected trade matrix with the same total volumes of trade and modified trade flows to link primary exporters to final importers directly (Supplementary Methods).

For livestock products, all the emissions related to transport were allocated to livestock, but, for some feed products, we corrected the trade matrix to distinguish feed from food use. Among the different individual items considered, it was assumed that $100 \%$ of soybean cake, maize bran and wheat bran were used as feed (and hence allocated to livestock production). For the other items (wheat, barley, maize grains, soybeans, palm and cassava), the total feed intake of all livestock species was retrieved from GLEAM, and we assumed that the total feed intake came from imports and national production proportionally to their relative value in each country (Supplementary Methods).

We estimated sea transport distances associated with the international trade of feed and livestock commodities on the database developed by CERDI (French Centre for Studies and Research on International Development) ${ }^{54}$. For major exporting or importing countries with a large area and several important ports (for example, Argentina, Australia, Brazil, Canada, China and the United States), sea distances were calculated by considering their two main ports (weighted average). A sea distance matrix for each feed commodity was thus created (Supplementary Methods)

We estimated the fuel consumption, assuming an average fuel consumption of $1.3 \mathrm{~g} \mathrm{t}^{-1} \mathrm{~km}^{-1}$ (Notteboom and Cariou, personal communication). We assumed that $86 \%$ of the fuel consumed was in the form of heavy fuel oil and the remainder in marine diesel oil across all countries ${ }^{55}$. We then used the European Environment Agency (EEA) methodology ${ }^{30}$ to calculate the total $\mathrm{NO}_{x}$ emissions by multiplying the distance and volume of a commodity in the corrected FAO trade matrix, as well as the associated fuel consumption and emission factors. Finally, we assigned $\mathrm{NO}_{x}$ emissions to each production system proportionally to the volume of feed commodity used (Supplementary Methods).

$N$ losses during manure management. We utilized the method developed by EEA to estimate $\mathrm{N}$ emissions associated with manure management ${ }^{30}$. This method estimates $\mathrm{N}$ emissions from animal houses or yards and manure storage from the fraction of the total ammoniacal nitrogen (TAN), which represents the total amount of $\mathrm{N}$ in the forms of $\mathrm{NH}_{3}$ and $\mathrm{NH}_{4}{ }^{+}$. We estimated TAN based on mineralized $\mathrm{N}$ in urine and faeces according to ref. ${ }^{31}$. $\mathrm{N}$ emissions were estimated by multiplying TAN by the share of each manure management category and the corresponding emission factor. For $\mathrm{NH}_{3}$, we considered emissions from house or yard and manure storage. For $\mathrm{N}_{2} \mathrm{O}$ emissions, leaching and direct and indirect emissions from manure storage were estimated (Supplementary Methods). The release of $\mathrm{N}_{2}$ was considered as a recycled flow to the atmosphere and, although calculated, it was excluded in the further analysis of $\mathrm{N}$ emissions. For $\mathrm{NO}_{x}$ emissions, we distinguished emissions from manure used as biofuel or incinerated to recover energy from those from manure management. $\mathrm{NO}_{3}{ }^{-}$ emissions were estimated based on manure leaching and unregulated disposal into surface and groundwater based on IPCC $^{49}$ and literature data ${ }^{56-61}$ (Supplementary Methods). We then estimated manure available for recycling that was used to compute the manure application and deposition rate in each pixel (Supplementary Methods). The detailed equations are provided in the Supplementary Methods.

$N$ losses beyond the farm gate. A mass-balance approach was used to estimate $\mathrm{N}$ emissions downstream of the farm as the difference between $\mathrm{N}$ in primary products and live-animals and $\mathrm{N}$ in final products. It was assumed that most $\mathrm{N}$ was lost in the form of wastewater and untreated organic wastes from slaughterhouses and milk processing plants.

Data description. The GLEAM database was completed and updated for some topics. For feed production, we used the new version of the Global Agro-Ecological Zones (GAEZ) yield maps ${ }^{62}$ for feed crops (resolution of 5 arcmin). We added new data on biological $\mathrm{N}$ fixation for legumes, estimated based on the Livestock Environmental Assessment and Performance (LEAP) Partnership guidelines ${ }^{63}$. For other non-legume crops, we considered default values from the literature ${ }^{64,65}$ Crop-specific data on synthetic fertilizer applications were obtained by dividing the total fertilizer consumption for each crop from the International Fertilizer Association (IFA) ${ }^{7}$ by the harvested area from FAOSTAT ${ }^{6}$ for the main fertilizer-consuming countries. Other data on synthetic fertilizer were obtained from the Common Agricultural Policy Regionalised Impact model (CAPRI) for Europe $^{66}$, and from ref. ${ }^{67}$ for the United States at a subnational level. For Australia, data were obtained from ref. ${ }^{68}$. For the rest of the world we used FAOSTAT data $^{6}$. For the fertilizer applied to the grassland, we used data from $\mathrm{IFA}^{7}$ and the literature ${ }^{34}$. Data on atmospheric $\mathrm{N}$ deposition were obtained from ref. ${ }^{69}$. Manure deposited on grassland and applied to cropland was calculated iteratively from the model, prioritizing the application of manure to available arable lands in the cell where it was produced before applying it to other surfaces (grassland or grazed marginal land; Supplementary Methods). Data on crop residues were calculated from GAEZ yield maps based on IPCC equations. Data on global land $\operatorname{cover}^{70}$, slope $^{71}$ and precipitation ${ }^{72}$ were used to calculate spatially explicit runoff rates (Supplementary Methods). For imported feed items, we estimated $\mathrm{N}$ inputs and yield data as the national average, in each importing country, from the values of exporting country weighted by the trade volumes reported in the FAO trade matrix $^{6}$, corrected for re-export. For countries with missing data, we filled gaps with regional or continental average data (Supplementary Methods).

For animal production, we collected additional data on manure management for the main livestock-producing countries. Data were based on national greenhouse gas inventories for Brazil, Australia, Japan, Switzerland and New Zealand, the $\mathrm{NH}_{3}$ inventory for the United States ${ }^{73}$ and national statistics for Canada $^{74}$. Data for the European Union were detailed at the NUTS2 level ${ }^{75}$, and 
data for China, India, Mexico and Vietnam were derived from the literature ${ }^{60,76-79}$ (Supplementary Table 8).

Reporting Summary. Further information on research design is available in the Nature Research Reporting Summary linked to this article.

\section{Data availability}

The data used in this study are available in the Supplementary Information and Extended Data Fig. 1. Additional data extracted from GLEAM 2.0 are provided as Source Data. The detailed raw data used in GLEAM 2.0 for this assessment are available upon request from the corresponding author. Source Data are provided with this paper.

\section{Code availability}

The $\mathrm{R}$ code used to estimate the $\mathrm{N}$ indicators is available at https://github.com/ uaimable/Global_Nitrogen_assessment. The detailed Python codes used in GLEAM 2.0 are available on request from the corresponding author.

Received: 3 January 2020; Accepted: 17 June 2020;

Published online: 6 July 2020

\section{References}

1. De Haan, C., Gerber, P. \& Opio, C. in Livestock in a Changing Landscape Vol. 1 (eds Steinfeld, H., Harold, A. M., Schneider, F. \& Neville, E. L.) 35-50 (Island Press, 2010).

2. Freeman, H., Thornton, P. K., van de Steeg, J. A. \& Mcleod, A. in Animal Production and Animal Science Worldwise. WAAP Book of the Year - 2006: A Review of Developments and Research in Livestock Systems Vol. 3 (eds Rosati, A., Tewolde, A. \& Mosconi, C.) 219-232 (Wageningen Academic Publishers, 2007)

3. Steffen, W. et al. Planetary boundaries: guiding human development on a changing planet. Science 347, 1259855 (2015).

4. Rockström, J. et al. A safe operating space for humanity. Nature 461, 472-475 (2009).

5. Galloway, J. N. et al. The nitrogen cascade. BioScience 53, 341-356 (2003).

6. Statistical Databases (Statistics Division, FAO, 2018); http://faostat3.fao.org/ home/E

7. Heffer, P., Gruère, A. \& Roberts, T. Assessment of Fertilizer Use by Crop at the Global Level (International Fertilizer Industry Assocication, 2017)

8. Sutton, M. A. et al. Our Nutrient World: the Challenge to Produce More Food and Energy with Less Pollution. Global Overview of Nutrient Management (Centre for Ecology and Hydrology on behalf of the Global Partnership on Nutrient Management and the International Nitrogen Initiative, 2013).

9. Galloway, J. N. et al. Transformation of the nitrogen cycle: recent trends, questions and potential solutions. Science 320, 889-892 (2008).

10. Sutton, M. A. et al. Towards a climate-dependent paradigm of ammonia emission and deposition. Phil. Trans. R. Soc. B 368, 20130166 (2013).

11. Hamilton, H. A. et al. Trade and the role of non-food commodities for globa eutrophication. Nat. Sustain. 1, 314-321 (2018).

12. Ascott, M. J. et al. Global patterns of nitrate storage in the vadose zone. Nat. Commun. 8, 1416 (2017).

13. Erisman, J. W. et al. Consequences of human modification of the global nitrogen cycle. Phil. Trans. R. Soc. B 368, 20130116 (2013).

14. Transforming our World: The 2030 Agenda for Sustainable Development General Assembly 70th Session (United Nations, 2015).

15. Bodirsky, B. L. et al. Reactive nitrogen requirements to feed the world in 2050 and potential to mitigate nitrogen pollution. Nat. Commun. 5, 3858 (2014).

16. Conijn, J. G., Bindraban, P. S., Schröder, J. J. \& Jongschaap, R. E. E. Can our global food system meet food demand within planetary boundaries? Agric. Ecosyst. Environ. 251, 244-256 (2018).

17. Springmann, M. et al. Options for keeping the food system within environmental limits. Nature 562, 519-525 (2018).

18. Oita, A. et al. Substantial nitrogen pollution embedded in international trade. Nat. Geosci. 9, 111-115 (2016).

19. Poore, J. \& Nemecek, T. Reducing food's environmental impacts through producers and consumers. Science 360, 987-992 (2018).

20. Leip, A. et al. Impacts of European livestock production: nitrogen, sulphur, phosphorus and greenhouse gas emissions, land-use, water eutrophication and biodiversity. Environ. Res. Lett. 10, 115004 (2015).

21. Global Livestock Environmental Assessment Model. Version 2. Data Reference Year: 2010 (FAO, 2018); http://www.fao.org/fileadmin/user_upload/gleam/ docs/GLEAM_2.0_Model_description.pdf

22. OECD-FAO Agricultural Outlook 2019-2028 (OECD Publishing/FAO, 2019).

23. Beig, G. et al. in The Indian Nitrogen Assessment 403-426 (Elsevier, 2017); https://doi.org/10.1016/B978-0-12-811836-8.00025-2

24. Van Damme, M. et al. Industrial and agricultural ammonia point sources exposed. Nature 564, 99-103 (2018).
25. Wint, G. R. W. \& Robinson T. P. Gridded Livestock of the World 2007 (FAO, 2007)

26. Gerber, P. et al. Tackling Climate Change through Livestock-a Global Assessment of Emissions and Mitigation Opportunities (FAO, 2013).

27. Bos, J. F. F. P. \& de Wit, J. Environmental Impact Assessment of Landless Monogastric Livestock Production Systems. Working Document Livestock and the Environment: Finding a Balance (FAO/World Bank/USAID, 1996); https:// research.wur.nl/en/publications/environmental-impact-assessment-oflandless-monogastric-livestock

28. Bouwman, L. et al. Exploring global changes in nitrogen and phosphorus cycles in agriculture induced by livestock production over the 1900-2050 period. Proc. Natl Acad. Sci. USA 110, 20882-20887 (2013).

29. van der Hoek, K. W. Nitrogen efficiency in global animal production. Environ. Pollut. 102, 127-132 (1998).

30. EMEP/EEA Air Pollutant Emission Inventory Guidebook 2016 (EEA, 2016).

31. Vonk, J. et al. Methodology for Estimating Emissions from Agriculture in the Netherlands-Update 2018. Calculations of $\mathrm{CH}_{4}, \mathrm{NH}_{3}, \mathrm{~N}_{2} \mathrm{O}, \mathrm{NO}_{x}, \mathrm{PM}_{10}, \mathrm{PM}_{2.5}$ and $\mathrm{CO}_{2}$ with the National Emission Model for Agriculture (NEMA) (Statutory Research Tasks Unit for Nature \& the Environment, 2018).

32. Gerber, P., Robinson, T., Wassenaar, T. \& Steinfeld, H. in Livestock in a Changing Landscape Vol. 1 (eds Steinfeld, H., Harold, A. M., Fritz, S. \& Laurie, E. N.) 51-66 (Island Press, 2010).

33. Sutton, M. A. et al. The European Nitrogen Assessment (Cambridge Univ. Press, 2011).

34. Lassaletta, L. et al. Food and feed trade as a driver in the global nitrogen cycle: 50-year trends. Biogeochemistry 118, 225-241 (2014).

35. The International Code of Conduct for the Sustainable Use and Management of Fertilizers (FAO, 2018).

36. Hendriks, C. et al. Ammonia emission time profiles based on manure transport data improve ammonia modelling across north western Europe. Atmos. Environ. 131, 83-96 (2016).

37. Lauer, M., Hansen, J. K., Lamers, P. \& Thrän, D. Making money from waste: the economic viability of producing biogas and biomethane in the Idaho dairy industry. Appl. Energy 222, 621-636 (2018).

38. van Grinsven, H. J. M., Erisman, J. W., de Vries, W. \& Westhoek, H. Potential of extensification of European agriculture for a more sustainable food system, focusing on nitrogen. Environ. Res. Lett. 10, 025002 (2015).

39. Bai, Z. et al. China's livestock transition: driving forces, impacts and consequences. Sci. Adv. 4, eaar8534 (2018).

40. Gerten, D. et al. Feeding ten billion people is possible within four terrestrial planetary boundaries. Nat. Sustain 3, 200-208 (2020).

41. Mapiye, O., Chikwanha, O. C., Makombe, G., Dzama, K. \& Mapiye, C. Livelihood, food and nutrition security in southern Africa: what role do indigenous cattle genetic resources play?. Diversity 12, 74 (2020).

42. Davis, T. C. \& White, R. R. Breeding animals to feed people: the many roles of animal reproduction in ensuring global food security. Theriogenology 150, 27-33 (2020).

43. World Livestock: Transforming the Livestock Sector through the Sustainable Development Goals 222 (FAO, 2018)

44. Mehrabi, Z., Gill, M., Wijk, M., van, Herrero, M. \& Ramankutty, N. Livestock policy for sustainable development. Nat. Food 1, 160-165 (2020).

45. Weiler, V., Udo, H. M., Viets, T., Crane, T. A. \& De Boer, I. J. Handling multi-functionality of livestock in a life cycle assessment: the case of smallholder dairying in Kenya. Curr. Opin. Environ. Sustain. 8, 29-38 (2014).

46. Sustainable Nitrogen Management UNEP/EA.4/L.16 (United Nations Environment Assembly of UNEP, 2019).

47. Kanter, D. R. et al. Nitrogen pollution policy beyond the farm. Nat. Food 1, 27-32 (2020).

48. Uwizeye, A., Gerber, P. J., Schulte, R. P. O. \& de Boer, I. J. M. A comprehensive framework to assess the sustainability of nutrient use in global livestock supply chains. J. Clean. Prod. 129, 647-658 (2016).

49. 2006 IPCC Guidelines for National Greenhouse Gas Inventories. Prepared by the National Greenhouse Gas Inventories Programme (IPCC, 2006).

50. Velthof, G. et al. Integrated assessment of nitrogen losses from agriculture in EU-27 using MITERRA-EUROPE. J. Environ. Qual. 38, 402-417 (2009).

51. Carslaw, D. C. \& Rhys-Tyler, G. New insights from comprehensive on-road measurements of $\mathrm{NO}_{x}, \mathrm{NO}_{2}$ and $\mathrm{NH}_{3}$ from vehicle emission remote sensing in London, UK. Atmos. Environ. 81, 339-347 (2013)

52. Technical Conversion Factors for Agricultural Commodities (FAO, 2003).

53. Kastner, T., Kastner, M. \& Nonhebel, S. Tracing distant environmental impacts of agricultural products from a consumer perspective. Ecol. Econ. 70, 1032-1040 (2011).

54. Bertoli, S., Goujon, M. \& Santoni, O. The CERDI-Seadistance Database (2016) https://halshs.archives-ouvertes.fr/halshs-01288748/document

55. Smith, T. et al. Third IMO Greenhouse Gas Study 2014, 327 (International Maritime Organization, 2014).

56. Bai, Z. et al. Nitrogen, phosphorus and potassium flows through the manure management chain in China. Environ. Sci. Technol. 50, 13409-13418 (2016). 
57. Bai, Z. et al. Changes in pig production in China and their effects on nitrogen and phosphorus use and losses. Environ. Sci. Technol. 48, 12742-12749 (2014).

58. Vu, Q. D. et al. Effect of biogas technology on nutrient flows for small- and medium-scale pig farms in Vietnam. Nutr. Cycl. Agroecosystems 94, 1-13 (2012)

59. Schaffner, M., Bader, H.-P. \& Scheidegger, R. Modeling the contribution of pig farming to pollution of the Thachin River. Clean Technol. Environ. Policy 12, 407-425 (2009).

60. Thu, C. T. T. et al. Manure management practices on biogas and non-biogas pig farms in developing countries-using livestock farms in Vietnam as an example. J. Clean. Prod. 27, 64-71 (2012).

61. Huang, W., Qiao, F., Liu, H., Jia, X. \& Lohmar, B. From backyard to commercial hog production: does it lead to a better or worse rural environment? China Agric. Econ. Rev. 8, 22-36 (2016).

62. Fischer, G. et al. Global Agro-ecological Zones (GAEZ v3. 0)-Model Documentation (IIASA, 2012).

63. Nutrient Flows and Associated Environmental Impacts in Livestock Supply Chains. Guidelines for Assessment (Version 1) (FAO, 2018).

64. Herridge, D. F., Peoples, M. B. \& Boddey, R. M. Global inputs of biological nitrogen fixation in agricultural systems. Plant Soil 311, 1-18 (2008).

65. Peoples, M. B. et al. The contributions of nitrogen-fixing crop legumes to the productivity of agricultural systems. Symbiosis 48, 1-17 (2009).

66. Leip, A., Britz, W., Weiss, F. \& de Vries, W. Farm, land and soil nitrogen budgets for agriculture in Europe calculated with CAPRI. Environ. Pollut. 159, 3243-3253 (2011).

67. Swaney, D. P., Howarth, R. W. \& Hong, B. Nitrogen use efficiency and crop production: patterns of regional variation in the United States, 1987-2012. Sci. Total Environ. 635, 498-511 (2018).

68. Navarro, J., Bryan, B. A., Marinoni, O., Eady, S. \& Halog, A. Mapping agriculture's impact by combining farm management handbooks, life-cycle assessment and search engine science. Environ. Model. Softw. 80, 54-65 (2016)

69. Dentener, F. Global Maps of Atmospheric Nitrogen Deposition, 1860, 1993 and 2050 (DAAC, 2006).

70. Latham, J., Cumani, R., Rosati, I. \& Bloise, M. FAO Global Land Cover (GLC-SHARE) Beta-Release 1.0 Database. 40 (FAO, 2014).

71. Reuter, H. I., Nelson, A. \& Jarvis, A. An evaluation of void-filling interpolation methods for SRTM data. Int. J. Geogr. Inf. Sci. 21, 983-1008 (2007).

72. Harris, I., Jones, P. D., Osborn, T. J. \& Lister, D. H. Updated high-resolution grids of monthly climatic observations-the CRU TS3.10 Dataset. Int. J. Climatol. 34, 623-642 (2014).

73. National Emission Inventory-Ammonia Emissions from Animal Husbandry Operations, 131 (EPA, 2004).

74. Manure storage in Canada in Farm Environmental Management in Canada (Statistics Canada, 2003).

75. Bioteau, T., Burton, C., Guiziou, F. \& Martinez, J. Qualitative Assessment of Manure Management in Main Livestock Production Systems and a Review of Gaseous Emissions Factors of Manure Throughout EU27 (European Commission, 2009).
76. Gupta, P. K. et al. Methane and nitrous oxide emission from bovine manure management practices in India. Environ. Pollut. 146, 219-224 (2007).

77. Mink, T., Aldrich, E. L. \& Leon, L. A. Anaerobic Biodigester Technology in Methane Capture and Manure Management in Mexico-The History and Current Situation, 110 (The International Renewable Resources Institute of Mexico \& Tetra Tech Es, Inc, 2015).

78. Dan, T. T. et al. Area-Wide Integration (AWI) of Specialized Crop and Livestock Activities in Vietnam (FAO. 2003).

79. Gao, Z. et al. Greenhouse gas emissions from the enteric fermentation and manure storage of dairy and beef cattle in China during 1961-2010. Environ. Res. 135, 111-119 (2014).

\section{Acknowledgements}

This work was supported by the Teagasc Walsh Fellowship Scheme (ref. 2012230), the Livestock Environmental Assessment Performance (LEAP) Partnership (GCP/GLO/369/ MUL) and the Livestock Information, Sector Analysis and Policy Branch (AGAL) of the Food and Agriculture Organization of the United Nations (FAO). This work was supported in part through the project 'Supporting the Implementation of the Koronivia Joint Work on Agriculture Roadmap' (GCP/GLO/998/GER) supported by the Federal Ministry of Agriculture (BMEL) of Germany. We thank G. Cinardi for supporting the modelling of ruminant systems, J. C. Lopes for her comments on an earlier version of this manuscript and G. Virgili and C. Ciarlantini for designing Fig. 1.

\section{Author contributions}

A.U., P.J.G., R.P.O.S., C.I.O. and I.J.M.d.B. designed the research. A.U. was the principal investigator, and A.U., M.R. and F.C. collected new data. F.T. and F.C. analysed FAO trade matrix and transport data. A.U., G.T. and A.F. developed the modelling procedures A.F. and G.T. analysed the geo-referenced information for the livestock systems. A.U. analysed $\mathrm{N}$ flows and indicators. M.R. designed the graphs and maps. A.U. wrote the draft paper. P.J.G., I.J.M.d.B., R.P.O.S., C.I.O., A.F., T.P.R., H.S., F.T., J.N.G., A.L. and J.W.E. contributed to the writing of the paper. P.J.G., C.I.O. and I.J.M.d.B. jointly supervised the research.

\section{Competing interests}

The authors declare no competing interests.

\section{Additional information}

Extended data is available for this paper at https://doi.org/10.1038/s43016-020-0113-y.

Supplementary information is available for this paper at https://doi.org/10.1038/ s43016-020-0113-y.

Correspondence and requests for materials should be addressed to A.U.

Reprints and permissions information is available at www.nature.com/reprints.

Publisher's note Springer Nature remains neutral with regard to jurisdictional claims in published maps and institutional affiliations.

(c) The Author(s), under exclusive licence to Springer Nature Limited 2020 


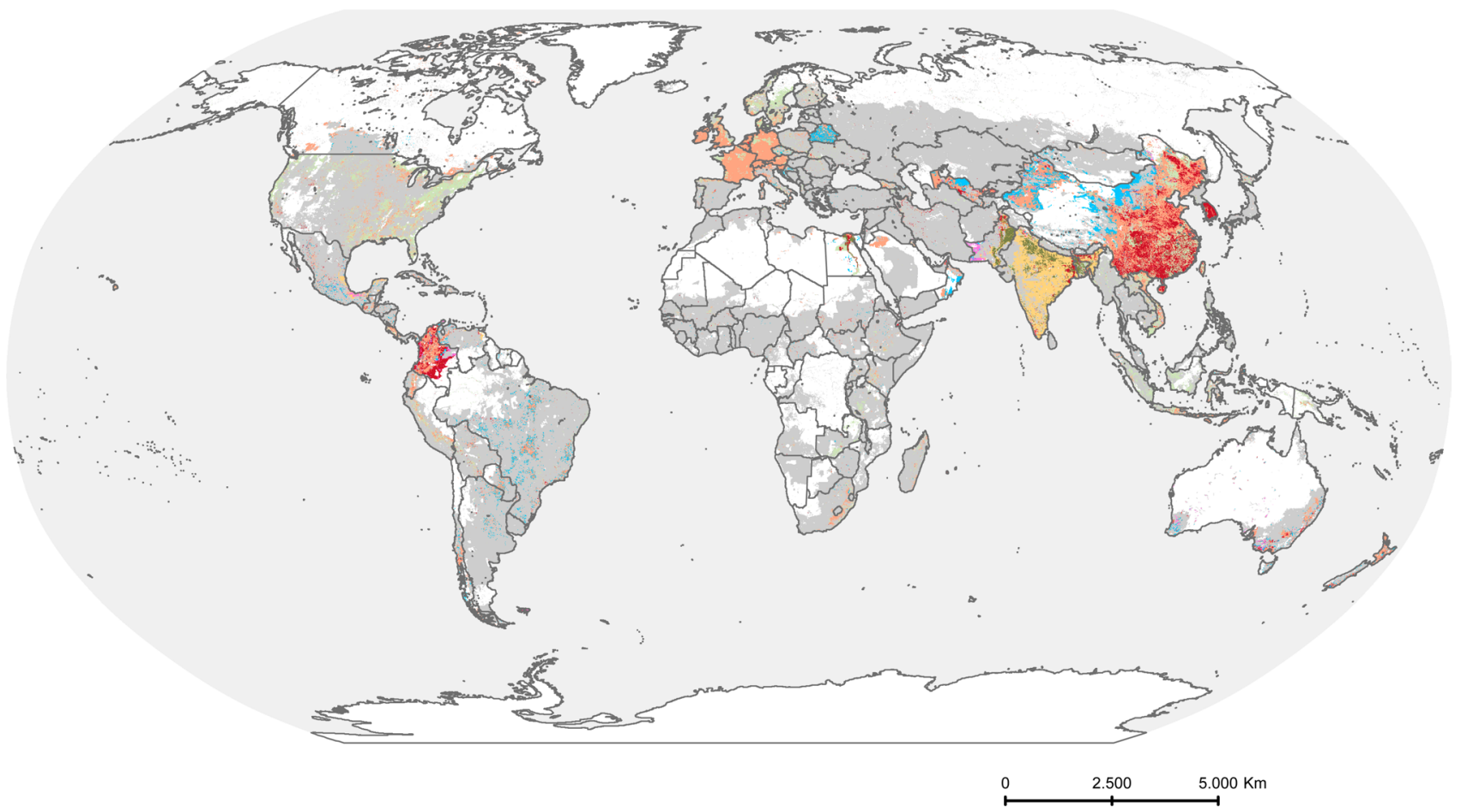

$\mathrm{N}_{2} \mathrm{O}, \mathrm{NH}_{3}$ and $\mathrm{NO}_{3}{ }^{-}$emissions hotspots from livestock supply chains

$\underset{\text { Low losses }}{\square \mathrm{NO}_{3^{-}}} \square \mathrm{NH}_{3} \square \mathrm{N}_{2} \mathrm{O} \underset{\text { Animal density < } 1 \text { livestock unit per sq. km }}{\square} \mathrm{NO}_{3^{-}}, \mathrm{NH}_{3} \square \mathrm{NH}_{3} \mathrm{O}, \mathrm{NH}_{3} \square \mathrm{NO}_{3^{-}}, \mathrm{NH}_{3}, \mathrm{~N}_{2} \mathrm{O}$

Extended Data Fig. 1 | Hotspots of $\mathrm{N}_{2} \mathrm{O}, \mathrm{NH}_{3}$ and $\mathrm{NO}_{3}{ }^{-}$emissions from global livestock supply chains. The map shows classes of hotspots in which one or more $\mathrm{N}$ compounds are concentrated. 


\section{Reporting Summary}

Nature Research wishes to improve the reproducibility of the work that we publish. This form provides structure for consistency and transparency in reporting. For further information on Nature Research policies, see Authors \& Referees and the Editorial Policy Checklist.

\section{Statistics}

For all statistical analyses, confirm that the following items are present in the figure legend, table legend, main text, or Methods section.

n/a Confirmed

\ $\square$ The exact sample size $(n)$ for each experimental group/condition, given as a discrete number and unit of measurement

Х $\square$ A statement on whether measurements were taken from distinct samples or whether the same sample was measured repeatedly

$\square$ The statistical test(s) used AND whether they are one- or two-sided

$\triangle \square$ Only common tests should be described solely by name; describe more complex techniques in the Methods section.

Х $\square$ A description of all covariates tested

Х $\square$ A description of any assumptions or corrections, such as tests of normality and adjustment for multiple comparisons

$\searrow \square$ A full description of the statistical parameters including central tendency (e.g. means) or other basic estimates (e.g. regression coefficient)

X AND variation (e.g. standard deviation) or associated estimates of uncertainty (e.g. confidence intervals)

$\square$ For null hypothesis testing, the test statistic (e.g. $F, t, r$ ) with confidence intervals, effect sizes, degrees of freedom and $P$ value noted

Х Give P values as exact values whenever suitable.

Х $\square$ For Bayesian analysis, information on the choice of priors and Markov chain Monte Carlo settings

Х $\square$ For hierarchical and complex designs, identification of the appropriate level for tests and full reporting of outcomes

Х $\square$ Estimates of effect sizes (e.g. Cohen's $d$, Pearson's $r$ ), indicating how they were calculated

Our web collection on statistics for biologists contains articles on many of the points above.

\section{Software and code}

Policy information about availability of computer code

Data collection No software was used for data collection. Data processing was performed using GLEAM 2.0.

Data analysis Data analysis on N flows was carried out with ESRI ArcGIS (version 10.3), using code scripts developed in Python (version 2.7.8). The estimation of the $\mathrm{N}$ use indicators, instead, was performed using $\mathrm{R}$ (version 3.6.1).

For manuscripts utilizing custom algorithms or software that are central to the research but not yet described in published literature, software must be made available to editors/reviewers. We strongly encourage code deposition in a community repository (e.g. GitHub). See the Nature Research guidelines for submitting code \& software for further information.

\section{Data}

Policy information about availability of data

All manuscripts must include a data availability statement. This statement should provide the following information, where applicable:

- Accession codes, unique identifiers, or web links for publicly available datasets

- A list of figures that have associated raw data

- A description of any restrictions on data availability

The results developed in this analysis are provided in the supplementary material and source data. The $\mathrm{R}$ code to estimate nitrogen use indicators at country level is available at https://github.com/uaimable/Global_Nitrogen_assessment 


\section{Field-specific reporting}

Please select the one below that is the best fit for your research. If you are not sure, read the appropriate sections before making your selection.
Life sciences
Behavioural \& social sciences
$\bigotimes$ Ecological, evolutionary \& environmental sciences

For a reference copy of the document with all sections, see nature.com/documents/nr-reporting-summary-flat.pdf

\section{Ecological, evolutionary \& environmental sciences study design}

All studies must disclose on these points even when the disclosure is negative.

Study description

The study consisted in the global analysis of nitrogen use, flows and emissions associated with the supply chains of six main livestock species (cattle, buffaloes, sheep, goats, pigs and chickens), including the international trade of feed and animal-source food. To this purpose, a specific methodology was developed to integrate and expand the spatially explicit model Global Livestock Environmental Assessment Model (GLEAM 2.0), which is based on a Life Cycle Assessment (LCA) approach. The analysis provides disaggregated information on nitrogen emissions at pixel level ( 5 arc minute) and nitrogen use efficiency indicators estimated at country level for different livestock production systems. This study aims to inform policy dialogue and design future change towards sustainable livestock agri-food systems.

Research sample

The study consider the global livestock sector including feed production and processing of animal-source food. No sampling was conducted. Data collection was based on existing datasets: Global agro-ecological zones (FAO GAEZ v4 reference year 2010, unpublished) for crop yield map ; fertilizers data were obtained from CAPRI model for EU, Swaney et al 2018 for US and Navarro et al 2016 for Australia, IFA data (2017), and FAOSTAT; livestock systems data were based on GLEAM 2.0 and Global Livestock of the World (GLW) model (version 2). Additional data were based on Latham et al 2014 (global land cover, GLC-SHARE), Reuter et al 2007 (slope), Harris et al 2014 (Precipitation) and national greenhouse gas emissions inventories. All these data were added in GLEAM 2.0 developed by FAO.

Sampling strategy No sampling strategy was required.

Data collection see above.

Timing and spatial scale

The analysis was conducted around 2010 at a global scale and the spatial unit of analysis was a pixel of approximately $10 \times 10 \mathrm{~km}$ at the equator.

Data exclusions

In Fig. 5.b data above $150 \mathrm{~kg} \mathrm{~N}$ ha-1 were excluded for better visualization.

Reproducibility

A consistency check was performed on data, equations and units of measurements.

Randomization

no randomization was required.

Blinding

No blinding was required.

Did the study involve field work? $\square$ Yes $\quad \backslash$ No

\section{Reporting for specific materials, systems and methods}

We require information from authors about some types of materials, experimental systems and methods used in many studies. Here, indicate whether each material, system or method listed is relevant to your study. If you are not sure if a list item applies to your research, read the appropriate section before selecting a response.

Materials \& experimental systems

$\mathrm{n} / \mathrm{a}$ Involved in the study

Х $\square$ Antibodies

\ $\square$ Eukaryotic cell lines

\ $\square$ Palaeontology

$\bigotimes \square$ Animals and other organisms

$\bigotimes \square$ Human research participants

\ $\square$ Clinical data

\begin{tabular}{l|l} 
Methods \\
\hline n/a & Involved in the study \\
$\square$ & $\square$ ChIP-seq \\
$\square$ & $\square$ Flow cytometry \\
$\searrow$ & $\square$ MRI-based neuroimaging
\end{tabular}

